\title{
Correction to: Toll-like receptor-mediated innate immunity against herpesviridae infection: a current perspective on viral infection signaling pathways
}

Wenjin Zheng ${ }^{1 \dagger}$, Qing Xu ${ }^{2 \dagger}$, Yiyuan Zhang ${ }^{1}$, Xiaofei $E^{3}$, Wei Gao ${ }^{4}$, Mogen Zhang ${ }^{1}$, Weijie Zhai ${ }^{1}$, Ronaldjit Singh Rajkumar ${ }^{1}$ and Zhijun Liu ${ }^{5^{*}}$

\section{Correction to: Virol J (2020) 17:192 \\ https://doi.org/10.1186/s12985-020-01463 \\ $-2$}

Following publication of the original article [1], the authors identified an error in the author name of Xiaofei $\mathrm{E}$. The given name and family name were erroneously transposed.

The incorrect author name is: E Xiaofei.

The correct author name is: Xiaofei E.

The author group has been updated above and the original article [1] has been corrected.

\section{Author details}

1 School of Basic Medical Sciences, Weifang Medical University, Wei-

fang 261053 , China. ${ }^{2}$ School of Anesthesiology, Weifang Medical University, Weifang 261053, China. ${ }^{3}$ Department of Microbiology and Physiological Systems, University of Massachusetts Medical School, Worcester, MA 01605 , USA. ${ }^{4}$ Key Lab for Immunology in Universities of Shandong Province, School of Basic Medical Sciences, Weifang Medical University, Weifang 261053, China. ${ }^{5}$ Department of Medical Microbiology, School of Basic Medical Sciences, Weifang Medical University, Weifang 261053, China.

Published online: 31 December 2020

*Correspondence: zhijun.liu@wfmc.edu.cn

${ }^{+}$Wenjin Zheng and Qing Xu have contributed equally to this work

${ }^{5}$ Department of Medical Microbiology, School of Basic Medical Sciences, Weifang Medical University, Weifang 261053, China

Full list of author information is available at the end of the article

\section{Reference \\ 1. Zheng et al. Virol J (2020) 17:192. https://doi.org/10.1186/s12985-020- 01463-2}

\section{Publisher's Note}

Springer Nature remains neutral with regard to jurisdictional claims in published maps and institutional affiliations.

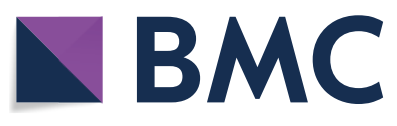

(9) The Author(s) 2020. Open Access This article is licensed under a Creative Commons Attribution 4.0 International License, which permits use, sharing, adaptation, distribution and reproduction in any medium or format, as long as you give appropriate credit to the original author(s) and the source, provide a link to the Creative Commons licence, and indicate if changes were made. The images or other third party material in this article are included in the article's Creative Commons licence, unless indicated otherwise in a credit line to the material. If material is not included in the article's Creative Commons licence and your intended use is not permitted by statutory regulation or exceeds the permitted use, you will need to obtain permission directly from the copyright holder. To view a copy of this licence, visit http://creativecommons.org/licenses/by/4.0/. The Creative Commons Public Domain Dedication waiver (http://creativeco mmons.org/publicdomain/zero/1.0/) applies to the data made available in this article, unless otherwise stated in a credit line to the data. 